
МАЙБУТНІХУЧИТЕЛІВ МУЗИЧНОГО МИСТЕЦТВА

9. Lerner, I. Ya. (1980). Protsess obucheniya i ego zakonomernosti [Educational process and its fundamentals]. Moscov, 96 p. [in Russian].

10. Maksymenko, S. D. (1994). Fakhivtsia potribno modeliuvaty [The specialist should be modelled]. Native school. Kyiv, No. 3-4. pp. 68-72. [in Ukrainian].

11. Moiseiuk, N. Ye. (2006). Hotovnist do profesiinoi diialnosti: sut i shliakhy formuvannia [Readiness for professional activity: essence and ways of its formation]. Modern information technologies and innovative teaching methods in specialist training: methodology, theories, experience, problems. Kyiv - Vinnytsia, vol. 12. pp. 364-368. [in Ukrainian].

12. Moroz, O. H., Slastonin, V. O. \& Filipchenko, N. I. (1997). Pidhotovka maibutnoho vchytelia: zmist ta orhanizatsiia [Future teacher training: essence and organisation]. Kyiv, 168 p. [in Ukrainian].

13. Mul, S. A. (2016). Psykholohiia hotovnosti ofitseraprykordonnyka do profesiinoi diialnosti. [Psycholofy of rediness of bourder guard officer for professional activity]. Doctor's thesis. Institute of psychology named after H. S. Kostiuk of NAPN of Ukraine. Kyiv, 364 p. [in Ukrainian].

14. Rezvan, O. O. (2013). Profesiini uminnia vypusknyka avtomobilno-dorozhnoi haluzi [Professional skills of automobile and road branch]. Pedagigy of creative personality formation in higher and high schools. Kyiv, vol. 30 (83). pp. 307-312. [in Ukrainian].

15. Tyklyuk, N. V.(2007). Gotovnost k deyatelnosti kak akmeologicheskiy fenomen [Readiness for activity as an akmeological phenomenon]. Acmeology. Moscov, No. 1. pp. 18-21. [in Russian].

Стаття надійшла до редакції 02.10.2019

УДК 37.091.12.011. 051:78.071.4

DOI:

Інна Шоробура, доктор педагогічних наук, професор, ректор Хмельницької гуманітарно-педагогічної академії Марина Михаськова, кандидат педагогічних наук, дочент, завідувач кафедри теорії та методики музичного мистеитвва Хмельницької гуманітарно-педагогічної академії

\title{
КОНЦЕПТУАЛЬНІ ІДЕЇ ФОРМУВАННЯ ДОСВІДУ МУЗИЧНО-ПЕДАГОГІЧНОӤ ДІЯЛЬНОСТІ МАЙБУТНІХ УЧИТЕЛІВ МУЗИЧНОГО МИСТЕЦТВА
}

У статті розглядається ідея формування досвіду музично-педагогічної діяльності майбутніх учителів музичного мистецтвва, заснована на інтегративності (міжпредметній та міжсалузевій), комплексності (багатокомпонентності), національній визначеності та системності, шуо регулюють практичні сторони навчально-виховного процесу, вимагають ділової співпраці й співтворчості викладача і студента, а також поєднання колективних форм навчання з індивідуальними.

Ключові слова: концептуальні ідё̈; досвід музично-педагогічної діяльності; вчитель музичного мистеитва.

Jim. 7.

Inna Shorobura, Doctor of Sciences (Pedagogy), Professor, Rector of the Khmelnytskyi Humanitarian-Pedagogical Academy Maryna Mykhaskova, Ph.D.(Pedagogy), Associate Professor, Head of the Theory and Methods of Music Art Department, Khmelnytskyi Humanitarian-Pedagogical Academy

\section{CONCEPTUAL IDEAS OF FORMING THE EXPERIENCE OF MUSIC-PEDAGOGICAL ACTIVITY OF THE FUTURE MUSIC ART TEACHERS}

The purpose of the article is to substantiate the concept of forming the experience of music-pedagogical activity of the future music art teachers in the practice of teaching in high school. The authors consider the experience of music-pedagogical activity as a product of methods and means of solving the set musical-pedagogical tasks, which is realized in music activity, based on all elements, obtained in the process of learning.

The scientific novelty of the article is in the fact of revealing the conceptual bases of forming the experience of music-pedagogical activity of the future teachers of music art, in which the authors took into account the philosophical, general scientific and socio-cultural aspects of professional training of music teachers; complex understanding of the end result of the formation of the experience of music-pedagogical activity has been crystallized; structural elements of the concept content have been selected in accordance with the professional activity of teachers of music art, taking into account the requirements of the current state standards of the specialty Secondary Education (Musical Art). The basic idea is based on unifying elements of integrity (cross-curricular and intersectoral), complexity (multi-components), national certainty and systematicity, which regulate the practical aspects of the educational process, require business cooperation and co-creation of the teacher and the student, as well as 


\section{КОНЩЕПТУАЛЬНІ ІДЕЇ ФОРМУВАННЯ ДОСВІДУ МУЗИЧНО-ПЕДАГОГІЧНОЇ ДІЯЛЬНОСТІ МАЙБУТНІХУЧИТЕЛІВ МУЗИЧНОГО МИСТЕЦТВА}

combination of collective forms of teaching with individual ones. It can be characterized as an algorithm of operations and actions, techniques, deeds and skills of the student, which are coordinated by the teacher from the beginning of the study to the final result of vocational training, which correspond to the educational-qualification characteristics of the graduate of the educational institution. In the process of mastering traditional and innovative methods, the specialist learns the ways of performing operations and actions, resulting in the constant development of individual experience, practical skills and professional knowledge.

Keywords: conceptual ideas; an experience of music-pedagogical activity; a teacher of music art.

П остановка проблеми. Актуальність розробки концепції обумовлена реформою в галузі шкільної музичної освіти, спрямованою на перебудову організації освітнього простору в загальноосвітніх школах, на зміну пріоритетів освіти. Оскільки заклади вищої освіти готують фахівців до роботи в школі, то й повинні реагувати на освітні перетворення в Україні новими підходами до підготовки фахівців, переглядом теоретико-методологічних основ музичної освіти, розробкою й практичним упровадженням нових освітніх технологій. Система музичної освіти нині перебуває на важливому етапі переходу й вимагає зміни змісту підготовки, обгрунтування наукових підходів. Наша концепція орієнтована на оволодіння досвідом вирішення життєвих питань, соціальних функцій, які можуть виникнути в майбутніх учителів музичного мистецтва в процесі роботи в закладах загальної середньої освіти.

Аналіз основних досліджень і публікацій. Досвіду педагогічної діяльності вчителів присвячені роботи О. Абдулліна, І. Зязюна, Н. Кузьміної, Н. Кухарєва, Т. Кліменко, С. Ніколаєнко, В. Решетько, Я. Турбовского, Р. Хрустальова. У сфері виконавської діяльності музикантів проблема розвитку музично-педагогічного досвіду висвітлювалась у працях О. Рудницької, О. Хлєбнікової; досвід вчителя музики в системі неперервної педагогічної освіти вивчала Н. Попович. Однак дослідження цих та інших учених не спрямовані на вивчення концептуальних ідей системи організації фахової підготовки вчителів музичного мистецтва, зокрема досвіду музичнопедагогічної діяльності.

Формування мети статті. Метою статті $\epsilon$ обгрунтування концептуальних ідей формування досвіду музично-педагогічної діяльності майбутніх учителів музичного мистецтва в практиці викладання вищої школи.

Виклад основного матеріалу дослідження. Головне призначення концепції - в інтеграції певного масиву знання [7, 38] як основної ідеї будь-якої теорії, головного задуму, оскільки вона існує як конструкція, побудова, експлікація знань [5].

За визначенням Е. Панасенко, “елементами концепції є не ідеальні об'єкти, аксіоми та поняття, а концепти - стійкі смислові згущення, що функціонують під час діалогу і комунікації' $[4,12]$. Розкриваючи вимоги до концепції, автор вказує, що вона повинна “містити нову оригінальну (порівняно $з$ раніше розробленими) ідею, на підставі якої вибудовується система знань про об’ єкт концепції; замикати в собі провідний задум і конструктивний принцип” $[4,13]$.

Так, серед концептуальних аспектів, які визначають розвиток музичної освіти України в останні десятиріччя та спрямовують вектор змін на майбутнє, українська дослідниця Г. Падалка виділила такі:

- музична освіта є невід'ємним компонентом загальної освіти дітей, фактором духовного, культурного, художнього, творчого розвитку особистості;

- основу музичної освіти мають складати кращі здобутки національного українського мистецтва;

- музична освіта спрямовується на органічне поєднання трьох видів музичної діяльності учнів - пізнання, оцінювання, творення;

- у роботі вчителя музичного мистецтва слід ураховувати поєднання емоційних і раціональних, об'єктивних і суб' єктивних, свідомих і підсвідомих способів осягнення музики;

- музична освіта грунтується на загальних засадах педагогіки, теорії і методики навчання музики і є складником педагогіки мистецтва;

- забезпечення взаємозв'язку і взаємодії між професійною підготовкою педагогів-музикантів і музичним навчанням школярів;

- опора на визначення перспективних напрямків модернізації музичної освіти [3, 21]. На передбачення цих аспектів, на думку автора, потрібно спрямовувати професійну підготовку майбутніх учителів музичного мистецтва.

Натомість, досліджуючи професійне становлення вчителів мистецьких дисциплін, В. Орлов запропонував побудувати професійну освіту відповідно до таких концептуальних ідей:

- інтеграції психолого-педагогічних дисциплін і предметів естетичного циклу;

- інтенсифікації процесу навчання за допомогою інтерактивних форм і методів;

- рефлексивної основи навчання і учіння, детермінованої взаємозв'язком об'єктивних і суб'єктивних умов [2, 184]. 


\section{КОНЦЕПТУАЛЬНІ ІДЁ ФОРМУВАННЯ ДОСВІДУ МУЗИЧНО-ПЕДАГОГІЧНОЇ ДІЯЛЬНОСТІ МАЙБУТНІХУЧИТЕЛІВ МУЗИЧНОГОМИСТЕЦТВА}

Ці ідеї допомогли передбачити ключові перспективні цілі, основні стратегічні пріоритети, визначити напрямки і обгрунтувати умови та принципи практичного впровадження системи формування досвіду музично-педагогічної діяльності майбутніх учителів музичного мистецтва.

Метою нашої концепції $є$ визначення основних напрямків і чинників формування досвіду музично-педагогічної діяльності майбутніх учителів музичного мистецтва, як-от: побудову педагогічної системи досліджуваного феномена, iii компонентів та структурних елементів, які приведуть до якісно нового рівня музичнопедагогічної освіти, суттєво покращать результати діяльності факультетів мистецтв та музичнопедагогічних факультетів.

Стратегічними напрямками концепції ми передбачаємо врахування основ інтегративного розвитку мистецької галузі як провідного чинника модернізації професійної підготовки майбутніх учителів музичного мистецтва та розвитку музично-педагогічної практики.

Ідея формування досвіду музично-педагогічної діяльності майбутніх учителів музичного мистецтва заснована на інтегративності (міжпредметній та міжгалузевій), комплексності (багатокомпонентності), національній визначеності та системності і спрямована на розвиток усіх компонентів досліджуваного феномена, що регулюють практичні сторони навчальновиховного процесу, вимагають ділової співпраці й співтворчості викладача і студента, а також поєднання колективних форм навчання 3 індивідуальними. В основі концептуальної ідеї лежать принципи формування досвіду музичнопедагогічної діяльності педагога-музиканта (єдності свідомої та активної діяльності; цілісності й урізноманітнення всіх видів діяльності; емоційності навчання; творчої свободи у всіх видах діяльності).

Концепція формування досвіду музичнопедагогічної діяльності охоплює:

- обгрунтоване коло характеристик (компонентів), щоб ії можна було швидко пізнати та відтворити;

- кожний елемент продовжує і доповнює попередні положення музично-педагогічної теорії;

- охоплює основні музично-педагогічні проблеми сучасності i, на нашу думку, $\epsilon$ універсальним варіантом їхнього вирішення;

- вибудована на науково вивірених основах музично-педагогічної діяльності, що $\epsilon$ результатом теоретичного аналізу сучасної теорії і практики музично-педагогічної освіти та індивідуальних особливостях дослідника;
- пов'язана 3 практичною діяльністю дослідника й враховує умови фахової діяльності;

- має доступне викладення основних положень.

Робота над концепцією була поділена за етапами, представленимив дослідженні І. Колєснікової [1, 184 - 187]. У процесі опису концепції формування досвіду музично-педагогічної діяльності майбутніх учителів музичного мистецтва автори враховували філософський, загальнонауковий і соціокультурний аспекти професійної підготовки вчителів-музикантів; викристалізовувалося комплексне розуміння кінцевого результату сформованості досвіду музично-педагогічної діяльності; обиралися структурні елементи змісту концепції відповідно до професійної діяльності вчителів музичного мистецтва 3 урахуванням вимог чинних державних стандартів спеціальності Середня освіта (Музичне мистецтво); аналізувався досвід музично-педагогічної діяльності педагогівмузикантів у міжнародній і вітчизняній практиці; проектувалися оптимальні умови реалізації досліджуваного феномена; вивчався стан сформованості основних компонентів фахової діяльності; структурувався зміст фахової підготовки майбутніх учителів музичного мистецтва; аналізувалися можливості наявних навчальних предметів і дисциплін у вирішенні зазначених проблем; проектувалась структурнофункціональна модель формування досвіду музично-педагогічної діяльності майбутніх учителів музичного мистецтва; прогнозувалося подальше концептуальне опрацювання кожного 3 виділених структурних компонентів змісту досліджуваного феномена

Автори запропонували певні зміни в технологію проведення лекцій, семінарів, лабораторних і практичних занять, індивідуальнодослідні навчальні завдання, самостійну роботу студентів, основані на нових формах і методах засвоєння досвіду музично-педагогічної діяльності особистості фахівця з музичного мистецтва.

До технології формування досвіду музичнопедагогічної діяльності майбутніх учителів музичного мистецтва належать:

- організація практичних інтегративних занять;

- підготовка і конструювання основ діалогової взаємодії між викладачем і студентами на основі емоційного і раціонального, об'єктивного й суб'єктивного, свідомого і підсвідомого;

- розвиток комплексної триєдності пізнання, оцінювання і творення в процесі навчальної діяльності;

- розвиток умінь прогнозувати та корегувати зміст дій і операцій у фаховій діяльності. 


\section{КОНЩЕПТУАЛЬНІ ІДЕЇ ФОРМУВАННЯ ДОСВІДУ МУЗИЧНО-ПЕДАГОГІЧНОЇ ДІЯЛЬНОСТІ МАЙБУТНІХУЧИТЕЛІВ МУЗИЧНОГО МИСТЕЦТВА}

Основну ідею формування досвіду музичнопедагогічної діяльності майбутніх учителів музичного мистецтва можна охарактеризувати як алгоритм операцій і дій, прийомів, учинків і навичок студента, які координуються викладачем від початку навчання до підсумкового результату професійної підготовки, які відповідають освітньокваліфікаційній характеристиці випускника навчального закладу. У процесі засвоєння традиційних та інноваційних методів відбувається засвоєння фахівцем способів виконання операцій і дій, у результаті чого здійснюється постійний розвиток індивідуального досвіду, практичних навичок та професійних знань. Це приводить до самовдосконалення індивіда, становлення його музично-педагогічної майстерності й утворення передового музично-педагогічного досвіду.

Кожний наступний етап професійної підготовки будується з розрахунком на вже освоєні студентом прийоми і способи дії, відбувається новий, відкоригований щабель здійснення способів діяльності. Студент є суб'єктом навчання і передбачає реакцію викладача на свої дії. Оцінює діяльність він з огляду на соціальні, професійні, етичні норми, які увійшли в процесі навчання в його досвід музично-педагогічної діяльності.

Ми запропонували збагачення музичнотеоретичних дисциплін інформативним матеріалом (інтегративними темами) стосовно методики викладання інтегрованого курсу “Мистецтво”. Побудова фахових курсів базується на виборі оптимальної моделі підготовки серед великої сукупності педагогічних технологій та інновацій і їхньої адаптації до специфічної підготовки музикантів-педагогів. В основу моделі покладені необхідні майбутньому вчителю музичного мистецтва компетентності, відповідно до професійних стандартів, які розглядаються комплексно. Це допоможе об'єднати традиційне навчання 3 інноваційними педагогічними технологіями в досліджуваній системі.

Комплексне об'єднання навчального матеріалу, взаємозв'язок і взаємопроникнення знань, умінь студентів забезпечують якість музичнопедагогічної підготовки. Це гарантується наявністю комплексних дисциплін у навчальному плані, комплексних видів занять 3 тими, хто отримує освіту, та проведенням комплексних іспитів під час підсумкової державної атестації випускників та семестрових екзаменів.

Оскільки вчитель музичного мистецтва є особистістю, яка вбирає велику кількість компонентів досвіду музично-педагогічної діяльності, то наступною особливістю системи $є$ багатокомпонентна підготовка майбутнього фахівця. Ураховуючи компоненти досвіду, які майбутній фахівець має засвоїти (когнітивний, результативно-практичний, комунікативний, емоційно-ціннісний, організаційно-прогностичний та творчий), та діяльності, яку має апробувати (творчу, гностичну, організаційну, комунікативну, аналітичну, конструктивну, проектувальну, діагностичну, прогностичну), майбутній спеціаліст отримує велику кількість інформації, яка забезпечує багатоплановість підготовки.

Учені Г. Падалка та О. Ростовський $[3,27 ; 6$, 178-179] акцентували увагу на необхідності національної визначеності програм музичної підготовки школярів, але забезпечити цю освіту покликані майбутні вчителі музичного мистецтва, тому й цей елемент був слушно доданий до нашої концепції та підкріплений змістом фахових дисциплін (“Музичний фольклор України”, “Історія української музики” тощо), які мають розкрити красу національного музичного мистецтва.

У процесі реалізації концепції передбачено використання таких механізмів: педагогічне прогнозування умов функціонування системи; проектування структурно-функціональної моделі формування системи; програмування (створення програм) формування системи; перетворення та модернізація структури. Практичне втілення концепції відбувається за допомогою реалізації інформаційних ресурсів, серед яких: здобуття і обмін інформацією, зокрема дистанційно та на індивідуальних заняттях; комплексна інформаційнометодична підтримка освітнього процесу кафедрами факультету; відкритий доступ до науково-методичних семінарів кафедри теорії та методики музичного мистецтва Хмельницької гуманітарно-педагогічної академії (наприклад, на тему “Методичні аспекти підготовки студентів до інноваційної діяльності зі спеціальності “Музичне мистецтво", "Концептуальні проблеми розвитку мистецької освіти”, “Удосконалення процесу підготовки педагогічних кадрів для Нової української школи в умовах реформування системи музичної освіти в Україні” тощо).

Висновки 3 цього дослідження і перспективи подальших розвідок у даному напрямку. Реалізація ідеї формування досвіду музично-педагогічної діяльності майбутніх учителів музичного мистецтва сприятиме створенню програм професійного розвитку педагогів-музикантів, забезпеченню скоординованої діяльності окремих напрямків фахової підготовки. Результатом реалізації концепції має стати утвердження в Україні моделі формування досвіду музично-педагогічної діяльності майбутніх учителів музичного мистецтва, підтвердження 
ефективності і використання системи досліджуваного феномена. Подальшого дослідження потребує питання впровадження дієвих механізмів корекції дій, операцій та вчинків у процесі навчання, які забезпечать у майбутньому розвиток педагогічної майстерності й стануть основою професіограми та передового педагогічного досвіду.

\section{ЛІТЕРАТУРА}

1.КолесниковаИ.А. Педагогическоепроектирование. Учеб. пособие для высших учебных заведений. Москва. 2005. С.184-187.

2. Орлов В.Ф. Професійне становлення вчителів мистецьких дисциплін. Ред. І.А. Зязюн. Київ. 2003. 276 с.

3. Козир А.В. (відп. ред.) Теорія та методика мистецької освіти. Наукова школа Г.М. Падалки. Колективна монографія. Київ. 2011. НПУ імені М.П. Драгоманова, 402 с.

4. Панасенко Е. А. Концепція історикопедагогічного дослідження: методологічний аналіз. Педагогічна освіта: теорія і практика. Психологія. Педагогіка. №25. 2016. С. 11-15. URL:http://nbuv.gov.ua/UJRN/Potip_2016_25 4.

5. Рижко В. А. Концепція. URL: http:// esu.com.ua/search articles.php?id=3256

6. Ростовський О.Я. Теорія і методика музичної освіти: Навч.-метод. посібник. Тернопіль: Навчальна книга-Богдан. 2011. 640 с.

7. Сурмін Ю.П. Майстерня вченого: Підручник науковця. Київ. 2006. С .38

\section{REFERENCES}

1. Kolesnykova, Y.A. (2005). Pedahohycheskoe proektyrovanye. Ucheb. posobye dlia vysshykh uchebnykh zavedenyi [Pedagogical Projecting]. Moscov, pp.184-187. [in Russian].

2. Orlov, V.F. (2003). Profesiine stanovlennia vchyteliv mystetskykh dystsyplin [Professional Formation of Teachers of Arts Disciplines]. (Ed.).I.A. Ziaziun. Kyiv, 276 p. [in Ukrainian].

3. Kozyr, A.V. (Ed.).(2011). Teoriia ta metodyka mystetskoi osvity. Naukova shkola H.M. Padalky. Kolektyvna monohrafiia [Theory and Methodology of Art Education. Scientific School of H.M. Padalka]. Kyiv, 402 p. [in Ukrainian].

4. Panasenko, E. A. (2016). Kontseptsiia istorykopedahohichnoho doslidzhennia: metodolohichnyi analiz. [The Concept of Historic-Pedagogical Research: Methodological Analysis]. Pedahohichna osvita: teoriia $i$ praktyka. Psykholohiia. Pedahohika. No.25. pp. 11-15. Available at: http:// nbuv.gov.ua/UJRN/Potip_2016_25 4. [in Ukrainian].

5. Ryzhko, V. A. (n.d.). Kontseptsiia [Concept]. Available at: http://esu.com.ua/search_articles. php?id=3256 [in Ukrainian].

6. Rostovskyi, O.Ya. (2011). Teoriia i metodyka muzychnoi osvity: Navch.-metod.posibnyk [Theory and Methodology of Music Education]. Ternopil, 640 p. [in Ukrainian].

7. Surmin, Yu.P. (2006). Maisternia vchenoho: Pidruchnyk naukovtsia [Scientist's Workshop: Scholar's Textbook]. Kyiv, p. 38. [in Ukrainian].

Стаття надійшла до редакції 03.10.2019

\section{G580}

"Музика своєю мелодією доводить нас до самого қраю вічності $і$ дає нам можливість протягом декількоххвилин осягнути ї̈ велич".

“Фва основних надбання людської природи - ие розум і міркування". Tiлутарх
давньогреиький письменник, філособ

"Мало одного знання - треба застосувати його. Мало хотіти - треба діяти." Йоганн Вольббтант фбон Тете німецький поет

“Яюби істину, але будь поблажливим до помилок”.

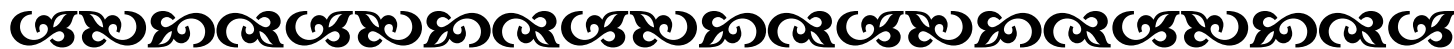

